\title{
Un largo proceso en la definición historiográfica de las fuentes del arte medieval: el arte antiguo como referente para la escultura románica
}

José Alberto Moráis Morán

\section{(2) OpenEdition}

\section{Journals}

Edición electrónica

URL: http://journals.openedition.org/medievalista/724

DOI: $10.4000 /$ medievalista.724

ISSN: 1646-740X

Editor

Instituto de Estudos Medievais - FCSH-UNL

Referencia electrónica

José Alberto Moráis Morán, « Un largo proceso en la definición historiográfica de las fuentes del arte medieval: el arte antiguo como referente para la escultura románica », Medievalista [En línea], 9 | 2011 , Puesto en línea el 02 enero 2011, consultado el 01 mayo 2019. URL : http://journals.openedition.org/ medievalista/724 ; DOI : 10.4000/medievalista.724 


\author{
Título: Un largo proceso en la definición historiográfica de las fuentes del \\ arte medieval: el arte antiguo como referente para la escultura románica. \\ Autor(es): José Alberto Moráis Morán \\ Enquadramento Institucional: Departamento de Arte y Ciencias del Territorio, \\ Facultad de Filosofía y Letras, Universidad de Extremadura. Grupo de \\ Investigación ARTARQ (Arte y Arquitectura desde la Antigüedad). \\ Contacto: jamorm@unileon.es \\ Fonte: Medievalista [Em linha]. №9, (Dezembro 2010). Direc. José Mattoso. Lisboa: IEM. \\ Disponível em: http://www2.fcsh.unl.pt/iem/medievalista/ \\ ISSN: $1646-740 \mathrm{X}$
}

\title{
Resumo
}

O presente artigo reflecte sobre os principais contributos historiográficos que se vêm desenvolvendo no âmbito do estudo do legado antigo, presente na escultura românica. Desde o surgimento do termo "Românico", criado por Charles de Gerville, em 1818, até à publicação, em 1960, da obra Renascimento e Renascimentos, por Erwin Panofsky, muitos foram os avanços realizados com o objectivo de clarificar a especificidade de tais influências. Assim, propomo-nos definir um quadro sincrónico, no qual se estruturam as investigações levadas a cabo, revelando-se a máxima actualidade de que o tema continua a revestir-se.

Palavras-chave: Românico; historiografia; escultura românica; arte medieval; fontes medievais.

\section{Abstract}

In this article it is reflected on the principal historiographic contributions around the study of the ancient legacy present in the Romanesque sculpture. Since the appearance 
of the "Romanesque" term, coined by Charles de Gerville in 1818, until the publication in 1960 of the Erwin Panofsky's book Renaissance and Renascences in Western Art, it was advanced a lot in the definition of such influences. Actually it is tried to present a synchronous panorama that allows to put into context the current researches on this highly topical subject.

Keywords: Romanesque; historiography; romanesque sculpture; medieval art; medieval sources.

\section{Un largo proceso en la definición historiográfica de las fuentes del arte medieval: el arte antiguo como referente para la escultura románica}

\section{José Alberto Moráis Morán}

Las reflexiones que siguen a estas breves palabras preliminares derivan, muy parcialmente, de algunos de los puntos que hemos abordado en distintas investigaciones sobre la escultura románica hispana ${ }^{1}$.

En particular, en esta ocasión se pondrá de relieve el largo proceso que, iniciado en el siglo XIX, acabaría desembocando en la configuración de un rico panorama

\footnotetext{
${ }^{1}$ Particularmente nos referimos a todas aquellas que han culminado con la defensa de la Tesis Doctoral y la obtención del Grado de Doctor con "Mención Europea". La investigación, titulada "El sustrato de la Antigüedad clásica en la escultura románica hispana", fue dirigida por la Dra. Etelvina Fernández González (Universidad de León) y obtuvo la calificación de Sobresaliente cum Laude tras su defensa el día 26 de febrero de 2010. La Comisión de Doctorado que valoró el trabajo estuvo formada por los doctores M. Valdés Fernández (Universidad de León), I. G. Bango Torviso (Universidad Autónoma de Madrid), J. Arce (Université Charles de Gaulle. Lille III), M. A. Castiñeiras González (Universitat Autónoma de Barcelona) y C. Cosmen Alonso (Universidad de León). Los informes necesarios para lograr la citada mención fueron elaborados por los doctores M. D’Onofrio (Università degli studi di Roma la Sapienza), M. A. Miranda (Universidade Nova de Lisboa) y D. Gregorio (Université de Valenciennes et du Hainaut Cambrésis). A todos ellos quiero agradecer la ayuda prestada a lo largo de estos años, sus sabios consejos y aportaciones al trabajo doctoral que hemos realizado.
}

Medievalísta online №9| Janeiro - Junho 2011 @ IEM - Instituto de Estudos Medievais 2 
historiográfico encargado de contextualizar, analizar y profundizar sobre el conocimiento del sustrato antiguo presente en la escultura de los siglos XI y XII.

Más allá de realizar una síntesis o un meticuloso estado de la cuestión sobre el tema, se pretenden poner de relieve aquellos estudios o análisis pioneros que, a posteriori, permitirán encuadrar las investigaciones realizadas a lo largo del siglo XX y los primeros decenios de este siglo XXI en el que nos encontramos inmersos. De ahí que se acuse la omisión intencionada de autores y estudios relevantes, olvidados con el mero hecho de plantear una dirección argumental coherente en el desarrollo del trabajo ${ }^{2}$.

\section{EL ORÍGEN DEL ROMÁNICO EN LAS TEORÍAS DECIMONÓNICAS Y SU PROYECCIÓN SOBRE LA LITERATURA CIENTÍFICA DEL SIGLO XX.}

Han pasado ya ciento noventa y dos años desde que Charles de Gerville (1769-1853) escribiera la célebre misiva del año 1818 en la que utilizaba, parece ser que por primera vez, la expresión "arte románico"3.

El dato es sobradamente conocido. Asistimos aquí a la invención de un nuevo concepto, de raigambre filológica, pero aplicado ahora sobre las manifestaciones plásticas de un periodo muy concreto de la historia del arte medieval ${ }^{4}$. Frente a la perfección técnica y la alta consideración del opus romanum, el "nuevo" arte románico era concebido como una degradación flagrante de aquella plástica imperial romana.

A pesar de la concepción peyorativa que emanaba de esta invención calculada por Gerville, las reacciones no se hicieron esperar. Apenas unos años después, en torno al 1824, el arqueólogo francés Arcisse de Caumont (1801-1873) publicaba un ensayo en el que abordaba el análisis de la arquitectura medieval francesa ${ }^{5}$. Se trataba del inicio de

2 El objetivo de nuestras reflexiones no pretende un estado de la cuestión. Cf.: N. DACOS, "Sopravvivenza dell'antico", Enciclopedia dell'arte antica classica e orientale, Roma, 1973, pp. 725746. Con un balance historiográfico completo.

${ }^{3}$ CH. DE GERVILLE, Voyage archéologique dans la Manche (1818-1820) édition annotée par le Dr. Michel Guibert, Paris, 1818-1820, (reed. 5 vols, 1999-2002).

Resulta paradójico, por ejemplo, que a este respecto J. Williams considere la fecha de 1893 como el origen historiográfico del arte románico en España, a propósito de la fundación de la Sociedad Española de Excursiones. Cf.: J. WILLIAMS, "El románico en España: diversas perspectivas", Alfonso VIII y su época, Madrid, 1992, pp. 9-20.

${ }^{4}$ J. HUBERT, “Archéologie médiévale”, L'Histoire et ses méthodes (Ch. Samarán ed.), Paris, 1961, pp. 275-328 y X. BARRAL I ALTET, Contre l'art roman ? essai sur un passé réinventé, Paris, 2006.

${ }^{5}$ A. DE CAUMONT, Essai sur l'architecture du moyen âge, particulièrement en Normandie, Paris, 1824.

Medievalista online № 9| Janeiro - Junho 2011 ๑ IEM - Instituto de Estudos Medievais 3 
un largo y lento proceso en la definición de una nueva tipología artística, enraizada plenamente en algunos de los preceptos definidos por Winckelmann (1717-1768) y adoptados y revisados, más tarde, en la Europa decimonónica por autores cercanos a los postulados historicistas ${ }^{6}$.

El nacimiento de la teoría del estilo románico presenta un punto fundamental en cuanto al papel que los distintos autores otorgaron al arte antiguo romano, entendido ahora como el germen inspirador de los postulados más definidores del arte y la arquitectura desarrollada en la Europa de las lenguas romances, durante los siglos XI y XII.

No se trata de un tema menor, pues, deduciblemente, la principal de las características que, originariamente, definiría este tipo de arte, sería su claro parentesco con respecto al arte romano ${ }^{7}$. Es dentro de esta dualidad estilística y bajo la inestable fundamentación de un sistema comparativo, donde se forjó una de las grandes corrientes historiográficas que dominarán el estudio de las fuentes del románico europeo, más allá de las eventuales razones, un tanto vagas e inexpertas, que elaboraron aquellos lejanos autores franceses decimonónicos.

Lejos quedaban ya las tendencias defendidas por el movimiento romántico, cuyo único interés en relación con el arte y la arquitectura del periodo medieval recaía, casi exclusivamente, en aquellas creadas durante los siglos del gótico ${ }^{8}$. El románico, en cierta medida olvidado y denostado, comprendido como el epílogo del arte antiguo y el prólogo de la arquitectura ojival ${ }^{9}$, comenzó a ser revalorizado a partir de ese año 1818.

\footnotetext{
${ }^{6}$ I. G. BANGO TORVISO, "Crisis de una historia del arte medieval a partir de la teoría de los estilos. La problemática de la Alta Edad Media", Revisión del arte medieval en Heuskal Herria, 15, 1995, pp. 15-28; J. PLAZAOLA, Modelos y teorías de la Historia del Arte, San Sebastián, 1987 y E. DE ORTUETA HILBERATH, "La visión de la construcción medieval desde la óptica de la era industrial", Libros con Arte. Arte con libros, Cáceres, 2007, pp. 565-581, en particular, p. 566.

${ }^{7}$ CH. DE GERVILLE, "Lettre adressée à M. de Vanssay, préfet du département de la Manche, en janvier 1820, contenant des recherches sur l'architecture des églises de ce département", Mémoires de la Société des Antiquaires de la Normandie, 1824, pp. 78-105. Por lo general, las reflexiones de este autor tendrían gran calado sobre la noción en torno al arte románico de otros autores coetáneos. En particular, además de hacer derivar los lenguajes y las formas estéticas de las producciones del siglo XI y XII con respecto a la tradición romana, también se comenzará a insistir en las peculiaridades propias de cada región. Cf.: X. BARRAL I ALTET, Contre l'art..., pp. 22-45.

${ }^{8}$ E. DE ORTUETA HILBERATH, “La visión de la construcción...”, p. 568.

${ }^{9}$ Para el caso hispano, por ejemplo, es significativa la expresión utilizada por algunos eruditos a la hora de catalogar ciertos edificios que hoy englobamos dentro del estilo románico. Por ejemplo, Isidro Bosarte considerará algunas de estas arquitecturas como encuadradas dentro del "gótico antiguo". Cf.: I. BOSARTE, Viaje artístico a varios pueblos de España con el juicio de las obras de las tres nobles artes que ellos existen y épocas a que pertenecen, Madrid, 1804, pp. 42-50.
}

Medievalista online No9| Janeiro - Junho 2011 () IEM - Instituto de Estudos Medievais 4 
A nuestro modo de ver, la defensa de su parentesco directo con respecto al magno arte la Antigüedad jugó un papel esencial en su reconsideración ${ }^{10}$.

\section{EL SIGLO XX Y LA ECLOSIÓN DEL PRISMA ANTIQUIZANTE CON EL QUE OBSERVAR EL ARTE ROMÁNICO.}

El impacto de las teorías francesas sobre el fuerte valor antiquizante del arte románico se amplificó como un eco sin solución de continuidad a lo largo de toda la centuria posterior, tal y como intentaremos sintetizar en las siguientes páginas.

En este sentido, baste con citar la publicación que veía la luz en el año 1987 y que fue firmada por Peter Burke (1937). Su pequeño ensayo, revelador en cuanto a la síntesis de los preceptos madurados durante más de un siglo por las élites culturales francesas, se materializó bajo el título de: El Renacimiento ${ }^{11}$. En esta obra, breve en cuanto a su extensión pero contundente en sus afirmaciones, el autor escribía:

“(...) casi todas las características que se atribuyen al Renacimiento pueden encontrarse también en la Edad Media, época con la que se suele contraponer. Y sucede que esta simple oposición binaria entre la Edad Media y el Renacimiento, tan útil a efectos explicativos, es en muchos casos errónea".

“(...) existen razones para afirmar que los llamados "hombres del Renacimiento" eran en realidad bastante medievales (...). Los medievalistas han reunido datos suficientes para afirmar que el Renacimiento no fue un acontecimiento singular. Existieron varios "renacimientos" en la Edad Media, especialmente en el siglo XII y en la época de Carlomagno. En ambos casos se produjo una combinación de logros artísticos y literarios, con un resurgimiento del interés por las enseñanzas clásicas, y también en cada uno de ellos los contemporáneos consideraron que la suya era una época de restauración, renacimiento o "renovación" 12 .

\footnotetext{
${ }^{10}$ N. PANADERO PEROPADRE, "La definición del estilo románico en la historiografía española del romanticismo", Anales de historia del arte, No 7, 1997, pp. 245-256.

${ }^{11}$ P. BURKE, El Renacimiento, Barcelona, 1999.

${ }^{12}$ Ibidem, pp. $12-13$ y p. 97.
} 
Las reflexiones de Burke muestran dos aspectos verdaderamente relevantes a la hora de circunscribir su figura dentro del marco historiográfico de la contemporaneidad. Por una parte, queda patente el rechazo y su correspondiente crítica al sistema ideológico defendido por el suizo Jacob Burckhardt (1818-1897), y su apoteósica y trascendente obra La cultura del Renacimiento en Italia ${ }^{13}$.

En dicho ensayo, este investigador defendía que el Renacimiento - con $\mathrm{R}$ mayúsculafue el gran acontecimiento cultural, artístico, económico y sociológico desde la caída del Imperio Romano y la disipación de los siglos de la Antigüiedad. El fenómeno renacentista era concebido entonces como un movimiento único, irrepetible y tan sólo vinculado, en su momento inicial, al ámbito italiano de finales del siglo XV y principios del XVI.

La idea de Burke según la cual "el Renacimiento de Burckhardt es un mito (...) es sinónimo de modernidad”, no deja lugar a dudas sobre su posicionamiento al respecto ${ }^{14}$. La diatriba en torno a esta querella entre los especialistas citados posee, no obstante, un estadio intermedio dentro de este proceso teórico que desembocó en la rotunda defensa de una progenie antiquizante del movimiento románico ${ }^{15}$.

Nos referimos, evidentemente, a una de las figuras más relevantes dentro de la intelectualidad en torno a las materias artísticas. Fue Edwin Panofsky (1892-1968) el autor que mejor supo aunar los primigenios balbuceos mostrados por la historiografía francesa y el método aplicado por Jacob Burckhardt sobre la figuración plástica y la arquitectura de lo que, hasta el momento, se entendía por Renacimiento.

\footnotetext{
${ }^{13}$ J. BURCKHARDT, Die Kultur der Renaissance in Italien, Basilea, 1860.

${ }^{14}$ P. BURKE, Op. cit., pp. 8-9.

15 Repetimos que no es nuestro cometido realizar un pormenorizado balance de todos los textos científicos aparecidos en el transcurso de estos años. Para la selección de los que aquí se analizarán han primado razones derivadas de la relevancia y originalidad de los mismos. Cf.: N. DACOS, Op cit., p. 742.
}

Medievalista online № 9| Janeiro - Junho 2011 ๑ IEM - Instituto de Estudos Medievais 6 


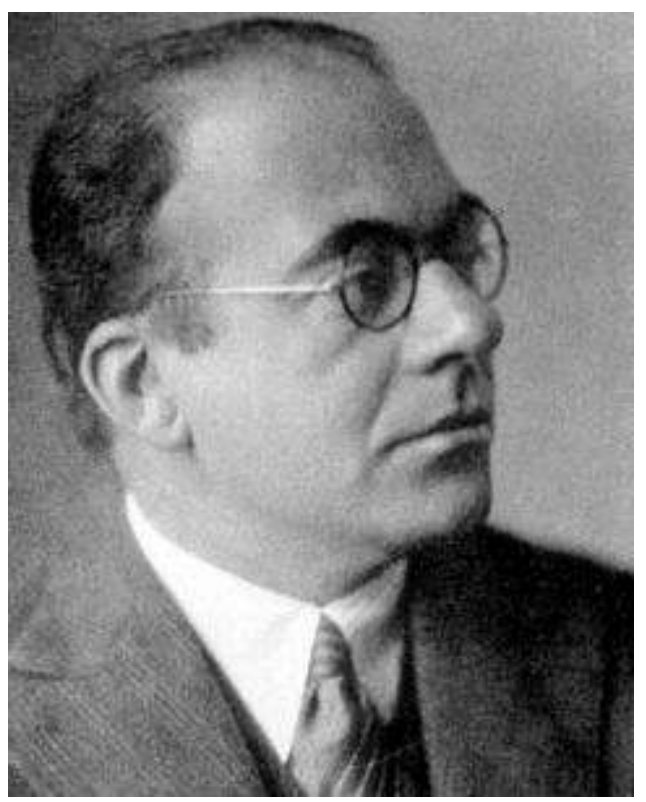

$\mathrm{Su}$ Renacimiento y renacimientos en el arte occidental, publicado en el año $1960^{16}$, debe considerarse, a nuestro juicio, como el germen inicial sobre el que partirán toda una larga nómina de teóricos actuales que defienden, con variable intensidad, la imposibilidad de considerar los fenómenos artísticos desarrollados en la Antigüedad clásica y la Edad Media como meros "subperiodos" separados y distantes, los unos con respecto a los otros, o meras categorías estancas y sin relación posible.

\section{Retrato de Erwin Panofsky}

\section{(C) New York University}

La obra del investigador alemán podría considerarse como el inicio de la ruptura de aquella división configurada en torno a lo que él definía como "megaperíodos", es decir, grandes momentos históricos amurallados e inconexos entre ellos ${ }^{17}$.

Tal grado de digresión, hacía necesario el establecimiento de un puente o salvoconducto entre ambos, de tal forma que, a través de tales planteamientos, la media aetas, el medium aevum o el media tempora, comenzasen a mostrarse y a ser entendidos como meros calificativos didácticos y referenciales de tintes utilitaristas, y no como dogmas de fe inamovibles.

La Edad Media no suponía una ruptura en la sucesión histórico-artística, sino un pasaporte de unión inmediata entre unos siglos -y más importante aún, unas gentes-

\footnotetext{
${ }^{16}$ E. PANOFSKY, Renaissance and Renascences in Western Art, New York, 1960. Este texto puede ser considerado como uno de los referentes fundamentales a la hora de comprender el fenómeno de recuperación de formas clásicas durante la Edad Media occidental y la construcción del "estilo" románico como deudor de las formas más representativas del arte romano. Dada la importancia del texto, consúltese también: ID., Renacimiento y renacimientos en el arte occidental, Madrid, 2004. En este trabajo utilizaremos, preferentemente, la edición más reciente.

${ }^{17}$ E. PANOFSKY, Renacimiento y renacimientos..., p. 33.
} 
que, en absoluto, se sentían partícipes de periodos herméticos y finitos ${ }^{18}$. Según esto, la prolongación de estos periodos artísticos en el espacio histórico debía considerarse como una segmentación artificial y controvertida, tan sólo útil a efectos prácticos ${ }^{19}$.

Esta nueva perspectiva de la realidad material en torno al arte de los siglos XV y XVI dejaba de configurar un "periodo" para convertirse en un "movimiento" 20 , mientras que la Edad Media pasaba a mantenerse unida al Renacimiento "por mil lazos; ya que la herencia de la Antigüedad clásica, por muy tenue que fueran a veces los hilos de la tradición, no llegó nunca a pederse de manera irrecuperable (...)"21.

Por lo general, esta obra citada de Panofsky suele considerarse como el punto de partida, dentro del ámbito científico europeo, de una nueva tendencia historiográfica que buscaba redefinir los lenguajes medievales con respecto al arte antiguo, acotar sus influencias y concretar la utilización de los conceptos y divisiones establecidas.

Ahora bien, sin restar valor a la obra de este insigne estudioso, acusamos quizá la sobredimensión que, durante las últimas décadas, ha alcanzado dicho texto. Una publicación, recordémoslo, del año 1960.

Pero, ¿qué había ocurrido desde aquel lejano año de 1818 hasta la publicación del trabajo de Panofsky dentro del estudio de las pervivencias clásicas en el arte románico?.

La estimación excesiva de la obra del alemán privó durante largo tiempo el reconocimiento de las investigaciones acometidas por otros autores que, aunque acreditados en los contextos especializados, han permanecido relegados al olvido frente a la celebridad de Renacimiento y renacimientos.

Mucho antes de que Panofsky, no lo olvidemos, compilara en forma de libro la serie de conferencias impartidas en el castillo de Gripsholm (Strängnäs, Suecia) durante el

\footnotetext{
18 Recordemos en este punto la frase de P. Burke: "existen razones para afirmar que los llamados "hombres del Renacimiento" eran en realidad bastante medievales". Cf.: P. BURKE, Op. cit., p. 12.

${ }^{19}$ E. SESTAN, “Tardo antico e alto Medievale: Difficoltà di una periodizzazione”, Actas IX Settimane di Studio del Centro Italiano di studi sull'Alto Medioevo. Il passaggio dall'Antichità al Medieoevo in Occidente, Spoleto, 1962, pp. 15-37; I. G. BANGO TORVISO, "Crisis de una historia...", pp. 15-28 e ID., "Un gravísimo error en la historiografía española, el empleo equivocado del término mozárabe", El legado de Al-Andalus. El arte andalusí en los reinos de León y Castilla durante la Edad Media (M. Valdés Fernández coord.), León, 2007, pp. 73-88.

${ }^{20}$ P. BURKE, Op. cit., p. 97.

${ }^{21}$ E. PANOFSKY, Renacimiento y renacimientos... (1985), p. 38.
} 
verano de $1952^{22}$, un amplio grupo de investigadores había retomado la primitiva idea de Gerville y la había llevado hasta límites que, en ocasiones, superaron con gran margen la obra del alemán; a pesar de que a él debemos la funcional idea de compendiarlos en un solo volumen, aún tratándose, como decimos, de estudios independientes ${ }^{23}$.

Un caso bien expresivo, especialmente en lo que concierne al conocimiento de las fuentes "clasiquizantes" de la escultura románica, lo representa un estudio publicado en 1906 por Émile Bertaux (1869-1917) ${ }^{24}$ y que supone la materialización de algunas de sus investigaciones sobre el arte español desarrollado con motivo de sus continuados viajes a la Península Ibérica a partir de 1904.

El autor francés, a propósito del estudio de la escultura de la iglesia de San Martín de Frómista $^{25} \mathrm{y}$, en particular, en relación con el célebre capitel ubicado sobre la columna adosada al pilar sur del ábside central decía: "difícilmente explicables (las formas e imágenes del capitel) sin el concurso de producciones clásicas ante los ojos del escultor".

Este maravilloso "presentimiento", tal y como lo definió M. Durliat ${ }^{26}$, seguramente insignificante ante la mirada crítica de un recién estrenado siglo XX, supuso una de las afirmaciones más importantes para el conocimiento del spolium in re dentro de la escultura románica hispana ${ }^{27}$.

22 J. F. YVARS, "Erwin Panofsky", Historia de las ideas estéticas y de las teorías artísticas contemporáneas (Valeriano Bozal Fernández coord.), vol. 2, Madrid, 1996, pp. 248-251.

${ }^{23}$ El texto de E. Panofsky acusa esta circunstancia, donde siempre sobrevuela la idea de la inconexión o la pérdida de un hilo argumental continuado en torno a los temas que estudia.

${ }^{24}$ E. BERTAUX, "La Sculpture chrétienne en Espagne des origines au XIVe siècle", Histoire de l'art, depuis les premiers temps chrétiens jusqu'à nos jours (M. André dir.), 18 vols., Paris, 1906, vol. II, pp. 214-295. Véase la biografía y la producción científica de este autor en la reciente aportación de: V. PAPA MALATESTA, "Émile Bertaux", Dictionnaire critique des historiens de l'art actifs en France de la Révolution à la Première Guerre mondiale (Ph. Sénéchal y C. Barbillon dir.), Paris, site web de l'INHA, 2009, consultado el 9 de junio de 2010: http://www.inha.fr/spip.php?article2196.

${ }^{25}$ Para un reciente estudio, incluyendo una pormenorizada visión del problema cronológico del templo, véase: J. L. SENRA GABRIEL Y GALÁN, "Architecture et décor dans le contexte de la colonisation clunisienne des royaumes septentrionaux de la péninsule ibérique", Hauts Linux romans dans le sud de l'Europe (XI-XII siècles). Moissac, Saint-Jacques de Compostelle, Modène, Bari..., Cahors, 2008, pp. 1170.

${ }^{26}$ M. DURLIAT, La sculpture romane de la route de Saint- Jacques. De Conques à Compostelle, Montde-Marsan, 1990, en concreto, pp. 286-287.

${ }^{27}$ Es decir, la reinterpretación iconográfica de los motivos decorativos e imágenes antiguas por parte de los artífices medievales. Cf.: S. SETTIS, “Continuitá, distanza, conoscenza. Tre usi dell'antico”, Memora dell'antico nell'arte italiana, Dalla tradizione all'archeología (a cura di S. Settis), vol. III, Turín, 1986,

Medievalista online № 9| Janeiro - Junho 2011 ๑ IEM - Instituto de Estudos Medievais 9 
El resto de este periplo historiográfico es bien conocido. Debemos al profesor Serafín Moralejo la conversión de ese "presentimiento" en un hecho histórico "verídico". Los escultores activos en la iglesia palentina de Frómista debieron inspirarse en algunas de las figuras del frontal de un sarcófago romano conservado por entonces en la colegiata de Santa María de Husillos, también en Palencia ${ }^{28}$. El augurio del francés daba paso a la realidad material románica y la concreción del profesor Moralejo atinaba sagazmente sobre los recursos plásticos utilizados por los obradores en la búsqueda de inspiración, hasta el punto de convertir este ejemplo en uno de los más claros y paradigmáticos de la Europa medieval $^{29}$, a pesar de que, en estos días, el fenómeno haya alcanzado niveles extraordinarios en cuanto a su valoración artística ${ }^{30}$.

La incipiente perspicacia de E. Berteux al presentir el sustrato antiguo de la escultura palentina refleja claramente la anticipación, si bien lejana, de algunos de los postulados metodológicos que, años más tarde, utilizaría E. Panofsky en la serie de conferencias antes mencionadas. No obstante comenzaban a asentarse las bases para el espectacular desarrollo del estudio de la filiación de la escultura románica con la plástica antigua.

Aún con todo se podría esgrimir, ante la tentativa de comparar un estudio global del fenómeno como el que supone el de Panofsky con respecto a esta mención esporádica realizada por Bertaux, una clara desventaja del francés con respecto al alemán.

pp. 372-486., en concreto p. 401; M. A. CASTIÑEIRAS GONZÁLEZ, "Capitel románico inspirado na Orestíada do sarcófago de Husillos", Luces de Peregrinación, Santiago de Compostela, 2004, pp. 252254 y L. DE LACHENAL, Spolia. Uso e reimpiego dell'antico. Dal III al XIV secolo, Milano, 1995, concretamente, pp. 11-30.

${ }_{28}$ Actualmente en Madrid, Museo Arqueológico. S. MORALEJO ÁLVAREZ, "Sobre la formación del estilo escultórico de Frómista y Jaca", Actas del XXIII Congreso Internacional de Historia del Arte, vol. I, Granada, 1973, pp. 427-434, consultado en Patrimonio artístico de Galicia y otros estudios: homenaje al Prof. Dr. Serafín Moralejo Álvarez (A. Franco Mata coord.), 3 vols., Santiago de Compostela, 2004, vol. I, pp. 65-70 e ID., "San Martín de Frómista en los orígenes de la escultura románica europea", Jornadas sobre el Románico en la Provincia de Palencia, Palencia, 1985, pp. 28-37, consultado en Patrimonio artístico de Galicia y otros estudios: homenaje al Prof. Dr. Serafín Moralejo Álvarez (A. Franco Mata coord.), 3 vols., Santiago de Compostela, 2004, vol. II, pp. 61 - 64.

${ }^{29}$ M. A. CASTIÑEIRAS GONZÁLEZ, "Verso Santiago? La sculptura romanica de Jaca a Compostella", Medioevo: l'Europa delle catedrali, Milano, 2007, pp. 387-396.

${ }^{30}$ En la Tesis Doctoral que hemos defendido ya explicamos la imposibilidad de recurrir exclusivamente a esta pieza romana para buscar referencias concretas para el arte románico hispano. Tanto para este edificio, como para la escultura de la catedral de San Pedro de Jaca o la colegiata de San Isidoro de León los referentes antiquizantes apuntan al conocimiento de un corpus mucho más rico y denso que el que, actualmente, hemos conservado. Cf.: F. PRADO-VILAR, "Del maestro de Orestes-Caín al maestro del sátiro: una conferencia sobre la belleza de la tragedia y la memoria del futuro", Maestros del románico en el Camino de Santiago, Aguilar de Campoo, 2010, pp. 11-46; ID., "Saevum facinus: Estilo, genealogía y sacrificio en el arte románico español", Goya, 324, 2008, pp. 173-199 e ID., "Lacrimae rerum: San Isidoro de León y la memoria del padre", Goya, 328, 2009, pp. 195-221. 
Sin embargo, tampoco fue Panofsky el primero de los autores en interesarse por el fenómeno del renacimiento de las artes y la cultura en el siglo XII desde una óptica amplia y común a toda Europa.

En enero del año 1927 Charles Homer Haskins (1870-1937) firma en Cambridge (Massachussets) la introducción a su obra The Renaissance of the $12^{\text {th }}$ century ${ }^{31}$.

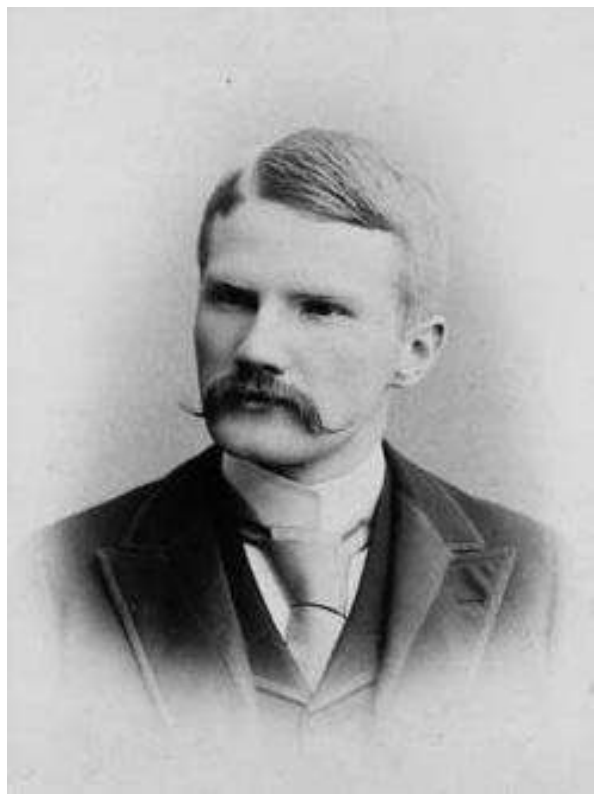

Retrato de Ch. Homer Haskins. C CESCM, Poitiers.

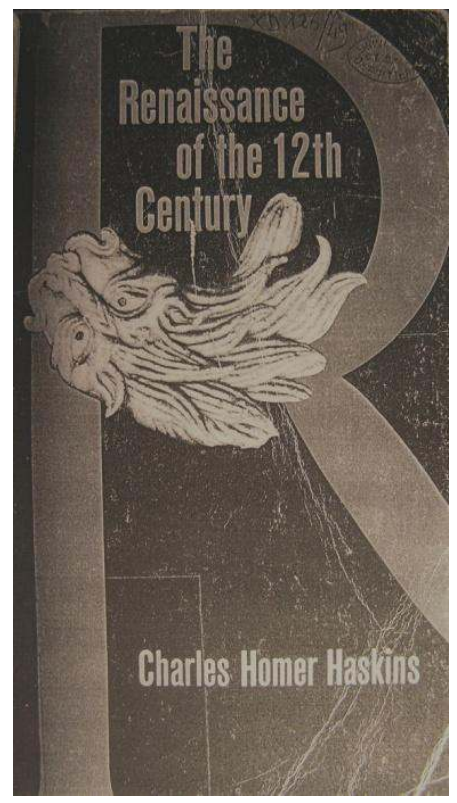

Portada del libro. 1927 (C) CESCM, Poitiers.

Las reflexiones realizadas por este autor supusieron un antecedente en toda regla a las ideas y posturas defendidas por Panofsky en su famoso libro. Más aún, Haskins expresa en el prefacio de su obra que su mismo título supone una flagrante contradicción al hablar de un renacimiento en el siglo XII; hecho que refleja, como ningún otro, la conflictividad abierta con respecto a las posturas, quizás inamovibles, de los sectores

\footnotetext{
${ }^{31}$ C. H. HASKINS, The Renaissance of the Twelfth Century, Cambridge, 1927. Además de esta obra tan relevante, citamos otras publicadas por los mismos años pero, a nuestro juicio, menos clarificadoras a la hora de comprender un fenómeno historiográfico de alcance global. Cf.: A. GRAF, Roma nella memoria e nelle immaginazioni del Medio Evo, Torino, 1882; E. MÜNTZ, "La tradition antique chez les artistes du Moyen Âge", Journal des savants, 1887, pp. 629-642; A. GOLDSCHMIDT, "Das Nachleben der antiken Formen im Mittelalter", Vorträge der Bibliothek Warburg, I, 1921-1922, pp. 40-50 y C. MOREY, "The sources of mediaeval style", Art Bulletin, 7, 1924, pp. 35-50.
} 
que se habían apropiado del término Renacimiento", como calificativo restringido a las producciones italianas y europeas de los siglos $\mathrm{XV}$ y $\mathrm{XVI}^{32}$.

Es evidente que el trabajo de Haskins fue manejado por Panofsky. El tratamiento que el primero de los autores realiza de diversas cuestiones relativas a la importancia de los centros intelectuales medievales, la conservación y difusión de la cultura clásica a través de la producción libraria y las bibliotecas, así como la preservación de los textos latinos, son puntos básicos que Panofsky tomó como referente para su estudio posterior. No obstante, el único aspecto oscuro que aún permanece sin aclarar en torno al libro de Haskins reside en la total omisión y olvido, quizás intencionado, de todos los temas relacionados con las artes plásticas y la arquitectura de los siglos XI y XII ${ }^{33}$.

Resultaría tedioso en el espacio del que disponemos examinar la nómina de trabajos que, desde un prisma u otro, aportaron novedades en torno a esta cuestión ${ }^{34}$. A pesar de ello los últimos años de la década de los treinta se nos presentan especialmente relevantes en este sentido. Fueron años cruciales en el avance de estos temas, gracias a la aparición de dos estudios fundamentales.

El primero de ellos al que queremos hacer referencia fue firmado por Dorothy Miner (1904-1973), historiadora del arte norteamericana y conservadora de obras manuscritas del Walters Art Museum de Baltimore. La obra vio la luz bajo el título de The survival of Antiquity in the Middle Ages. The Greek tradition ${ }^{35}$. La investigación, ciertamente interesante en muchos puntos, no llegó a tener el reconocimiento merecido debido a una fuerza mayor.

\footnotetext{
32 A este respecto, es muy significativo como el mismo Ernst Hans Josef Gombrich, (1909-2001) considerase a Antonio Pisanello, muerto en torno al año 1455, como el último de los grandes creadores de imágenes del periodo transitorio entre la Edad Media y el Renacimiento pues, según aclara, "el arte medieval tocó realmente a su fin, empezando el período conocido generalmente con el nombre de Renacimiento". Cf.: E. H. J. GOMBRICH, La Historia del Arte, Madrid, 2008, en particular, p. 221. Cf.: ID., The Story of Art, London, 1950 y M. BARASCH, Teorías del arte. De Platón a Winckelmann, Madrid, 1999, en particular, pp. 95-96.

Para un acercamiento a la cronología con la que, generalmente, los especialistas suelen barajar la introducción de las formas del Renacimiento en los territorios hispanos, véase: M. D. CAMPOS SÁNCHEZ-BORDONA, El arte del Renacimiento en León: las vías de difusión, León, 1992, en particular, pp. 11-22.

${ }^{33}$ C. H. HASKINS, Op. cit., pp. 70-71 y pp. 302-340.

${ }^{34}$ R. REY, "Quelques survivances antiques dans la sculpture romane du Midi de la France", Gazette des Beaux- Arts, II, 1928, pp. 173-191 y E. PANOFSKY y F. SAXL, "Classical Mythology in Medieval Art," Metropolitan Museum Studies, 4, 1932-1933, pp. 228-280.

${ }^{35}$ D. MINER, The survival of Antiquity in the Middle Ages. The Greek tradition, Baltimore, 1939.
} 
Dos años antes Henri Jacques Jean Adhémar (1908-1987) publicaba su celebérrimo libro Influences antiques dans l'art du Moyen Âge français; recherches sur les sources et les thèmes d'inspiration ${ }^{36}$.

La obra de este paleógrafo y conservador del Cabinet des estampes de la Bibliothèque nationale de París $^{37}$ supuso una absoluta renovación del panorama historiográfico internacional encargado de examinar estas cuestiones. Ello, sumado a su activa participación en la vida cultural parisina ofreció un revulsivo imparable para la difusión de su texto, si bien durante los primeros años desde su aparición la crítica en general no pareció demasiado impactada por su obra ${ }^{38}$.

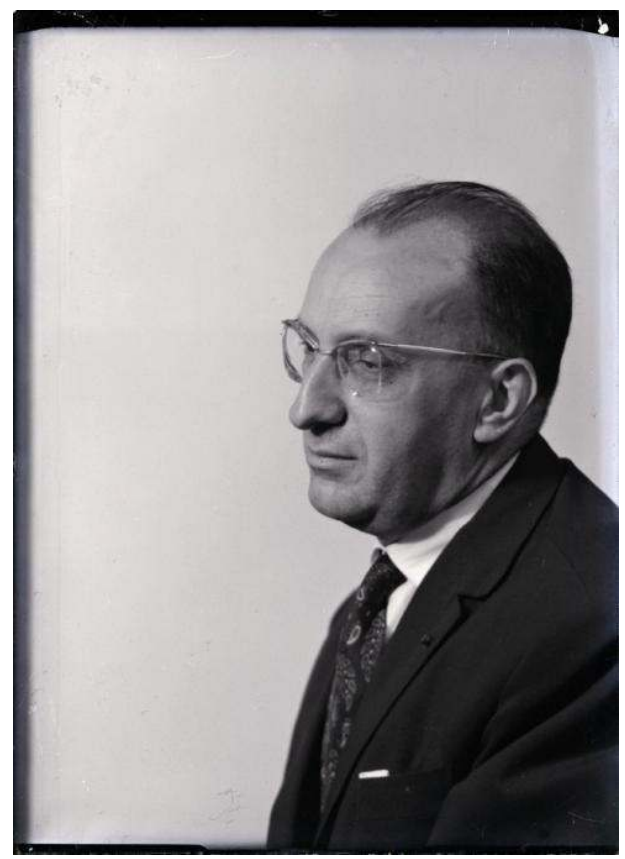

\section{Retrato de Jean Adhémar, por Man Ray. CMusée national d'Art moderne, Paris.}

\footnotetext{
${ }^{36}$ J. ADHÉMAR, Influences antiques dans l'art du Moyen-âge français: recherches sur les sources et les thèmes d'inspiration, London, 1937.

${ }^{37}$ F. SOUCHAL, "Chronique. Nécrologie. Jean Adhémar", Bibliothèque de l'école des chartes, 1988, vol. 146, 146-2, pp. 457-458 y D. DE FONT-REAULX, “Les audaces d'une position française”, Études photographiques, 25 mai 2010, pp. 70-105, en http://etudesphotographiques.revues.org/index3059.html, consultado el 29 de septiembre de 2010.

${ }^{38}$ D. DE FONT-RÉAULX, Op. cit. La autora analiza la importancia de este erudito en relación con su puesto como conservador en la biblioteca parisina, además de señalar su continuado contacto con figuras intelectuales de gran relevancia.
} 
No es fácil examinar detalladamente la figura, un tanto ecléctica, de este interesante autor. Las noticias biográficas que nos han llegado parecen un tanto confusas, en parte, derivadas de la crisis bélica europea. El origen del citado trabajo, según parece, tenía como germen inicial la elaboración de su Tesis Doctoral ${ }^{39}$.

El ambiente de formación de Adhémar no podía haber sido mejor. El director de la citada Tesis, Henri Focillon (1881-1943) había logrado constituir un nutrido grupo de jóvenes investigadores apasionados por el estudio del arte medieval y del que surgirían otra serie de figuras dignas de mención, tales como Georges Gaillard ${ }^{40}$, Louis Grodecki $^{41}$ o René Jullian ${ }^{42}$.

Este círculo cultural tomó pronto un rumbo conjunto con intereses semejantes. La Antigüedad era concebida como el eje central del que partían y se basaban gran parte de las novedades y avances de la escultura y la arquitectura románicas.

Tal y como se ha estudiado convenientemente, la relación directa entre J. Adhémar, E. Panofsky y otros autores de la categoría de Jean Seznec ${ }^{43}$, Fritz Saxl ${ }^{44}$ o la, ya citada, Dorothy Miner, seguro acabó por crear un rico clima "antiquizante" en el que poder proyectar los mismos intereses científicos.

\footnotetext{
39 Fue titulada: L'Antiquité classique dans l'art du Moyen Age français: études sur les sources d'inspiration plastiques et littéraires. Concretar el año en el que fue defendida nos sigue planteando dudas. Por una parte, según ha publicado León Pressouyre, ésta fue presentada en marzo del año 1938. Al contrario, entre los fondos históricos de la Bibliothèque del Centre d'études supérieures de civilisation médiévale de Poitiers, se conserva una copia de la misma datada en el año 1932. Cf.: Léon PRESSOYRE, "Préface", Influences antiques dans l'art du Moyen Âge français, Paris, reed. 1996.

${ }^{40}$ No es preciso insistir en la importancia de este autor y su obra como elementos indispensables para el conocimiento del arte románico hispano, además de sus continuadas referencias a la posible influencia del arte antiguo sobre dichas producciones. Véase, por ejemplo: Jean VALLERY-RADOT, "Georges Gaillard. Premiers essais de sculpture monumentale en Catalogne aux Xe et XIe siècles, Paris-Paul Hartmann, 1938. In-4 ${ }^{\circ}$ de 112 pages, 16 planches hors texte. Les débuts de la sculpture romane espagnole: León, Jaca, Compostelle, Paris-Paul Hartmann, 1938. In-4 de XXXV- 270 pages, 218 planches hors texte", Revue d'histoire de l'Église de France, 1939, vol. 25, 107, pp. 214-219.

${ }^{41}$ L. GRODECKI, The Year 1200. A Symposium, New York, 1975; ID., The Year 1200. A Background Survey, New York, 1970 e ID., "Le Style 1200”, Encyclopedia Universalis, Suplément II, 1980, pp. 13371340.

${ }^{42}$ René JULLIAN, "L'art de la draperie dans la sculpture romane de Provence", Gazette des Beaux-Arts, 1928, II, pp. 241-258. En esta aportación, muy temprana, el autor hace derivar algunos ejemplos de escultura románica de las experiencias galorromanas. En particular, estudia casos como los elementos textiles de las fachadas de Saint-Gilles o Saint-Trophime de Arles. Véase también: ID., "Les survivances antiques dans la sculpture lombarde", Études italiennes, I, 1931, pp. 131-140.

43 J. SEZNEC, La survivance des dieux antiques, London, 1940.

${ }^{44}$ E. PANOFSKY y F. SAXL, “Classical Mythology...”, pp. 228-280. Ya en torno a 1922 Saxl había ofrecido a la comunidad científica una pequeña aportación sobre este tema: F. SAXL, "Rinascimento dell'antichitá. Studien zu den Arbeiten A. Warburgs", Repertorium für Kunstwissenschaft, 43, 1922, pp. 220-272.
} 
Con todo, la obra del francés parece emanciparse de una tradición, ya por estos momentos bien arraigada, que utilizaba el término "Renacimiento" para definir estos ecos antiguos durante el periodo medieval. Como ha señalado L. Pressouyre, Adhémar logra renovar con su obra un conflictivo panorama sin tomar parte en la puja intelectual por el término "Renacimiento", llegando a minimizar incluso obras que conocía sobradamente, como aquellas de C. H. Haskins o la de Richard Hamann ${ }^{45}$.

El texto de Jean Adhémar se inicia con la alusión a los primeros teóricos que comenzaron a defender la continuidad de ciertas formas artísticas antiguas y medievales. Las citas que realiza a los textos del religioso italiano Luigi Antonio Muratori (1672-1750) ${ }^{46} \mathrm{y}$, especialmente, a las posturas expuestas por Arcisse de Caumont $^{47}$, sirven a Adhémar como base para justificar el legado antiguo presente en el arte medieval.

El alto conocimiento que el francés poseía sobre manuscritos y fuentes documentales, relacionados con su papel como archivero y paleógrafo, le permitió ofrecer una visión ciertamente amplia, rica y novedosa del traspaso de ciertos ecos antiguos sobre la iluminación medieval, así como la preservación de obras literarias antiguas dentro de los scriptoria monásticos ${ }^{48}$.

Desde luego, si la obra de Adhémar acabó por convertirse en uno de los referentes clásicos de la bibliografía especializada, primordialmente, frente al texto de Dorothy Miner, se debe, según pensamos, a la concreción, más razonable y verídica, de las fuentes antiquizantes utilizadas por los artífices medievales en suelo francés.

Mientras Miner argumentaba la importancia del sustrato grecohelenístico y su impronta en el ámbito medieval europeo, Adhémar pugnaba por unas relaciones más directas y

\footnotetext{
45 Léon PRESSOYRE, Op. cit., p. XIII. Cf.: R. HARMANN, Deutsche und französische Kunst im Mittelalter. I. Südfranzösische Protorenaissance und ihre Ausbreitung in Deutschland auf dem Wege durch Italien und sie Schweiz, Marbourg, 1922.

${ }^{46}$ J. ADHÉMAR, Op. cit., p. XI y L. A. MURATORI, Antiquitates italicae medii aevi, vol. II, 1739, "De Artibus Italicorum post inclinationem Romani Imperii dissertatio vigesimaquarta”, cols. 349-296.

47 Adhémar cita el trabajo de A. DE CAUMONT, Abécédaire ou rudiment d'archéologie, Paris-CaenRouen, 1858, pp. 2-36.

${ }^{48}$ É. A. VAN MOÉ, “Jean Adhémar. Influences antiques dans l'art du Moyen-âge français: recherches sur les sources et les thèmes d'inspiration, Londres, The Warburg Institute, 1937 , In- $8^{\circ}$, XVII-319 p. et XL planches et phototypie”, Bibliothèque de l'école des chartes, 1938, vol. 99, Numéro 1, pp. 380-382. Poco tiempo después y basándose en los avances de Adhémar, se firmaba un estudio monográfico sobre este tema. Cf.: P. COURCELLE, "La tradition antique dans les miniatures inédites du Virgile de Naples", Mélanges d'archéologie et d'histoire, 56, 1939, pp. 249-279.
} 
provinciales, acotando el campo comparativo, específicamente, al arte galorromano ${ }^{49}$. Pensamos que esta cercanía entre la fuente de inspiración y sus remedos románicos fue uno de los grandes aciertos de la obra del francés.

A pesar de todo, aún tendríamos que esperar hasta el año 1959 para que se hiciese pública la que, a nuestro juicio, es el gran último estudio antes de la irrupción del texto de E. Panofsky.

Ese año Walter Fraser Oakeshott (1903-1987) firmaba Classical Inspiration in Medieval $\mathrm{Art}^{50}$. Rector del Lincoln College de Oxford, supo aunar en su obra toda una serie de elementos avanzados en las producciones científicas anteriores. Sin olvidar la contextualización sociocultural de los siglos del románico y el gótico y la fundamental preservación de las fuentes latinas en los ambientes más refinados de esos periodos; Oakeshott lleva a cabo una densa equiparación entre las artes de la Antigüedad y el Medievo. Ahora bien, resultan patentes ciertas deficiencias del método de análisis utilizado, bien a pesar de que los resultados son enormemente expresivos y sugerentes ${ }^{51}$. En particular nos referimos a la supremacía con que trata el tema de los modelos clásicos y su representatividad dentro de la escultura románica, pero relacionados y yuxtapuestos siempre bajo un método puramente comparativo.

No podemos analizar concienzudamente el texto de Oakeshott, sin embargo, queremos remarcar algunos aspectos que nos parecen relevantes. En un claro precedente del texto de Panofsky, a pesar de ello, desconocido o no mencionado en Renacimiento y renacimientos $^{52}$, Oakeshott realiza un periplo a través de los principales movimientos recuperadores de los lenguajes artísticos antiguos desde los siglos VIII al XII ${ }^{53}$.

\footnotetext{
${ }^{49}$ En los meses durante los cuales el francés trabajó en su obra científica se estaba realizando la Tesis Doctoral de: M. DURAND LEFEBVRE, Art gallo-romain et sculpture romane. Recherches sur les formes, Paris, 1937. La recepción de las hipótesis defendidas en esta investigación doctoral no llegaron a alcanzar nunca el grado de impacto de las nociones y reflexiones de Adhémar.

${ }^{50}$ W. F. OAKESHOTT, Classical Inspiration in Medieval Art, London, 1959.

${ }^{51}$ Como en los lustros anteriores, entre la obra de Adhémar y la de Oakeshott fueron publicadas otras aportaciones. Cf.: R. CROZET, "De l'art romain à l'art roman. Recherches sur quelques ordonnances architecturales", XVII Congrès international d'histoire de l'art, Amsterdam, 1952, pp. 20-45; G. B. LANDER, "Some recent publications on the classical tradition in the Middle Ages and the Renaissance and on Byzantium", Traditio, 10, 1954, pp. 578-594 y J. BALTRUŠAITIS, Le Moyen Âge fantastique. Antiquités et exotismes dans l'art gothique, Paris, 1955.

${ }^{52}$ En ninguna parte del libro de Panofsky se hace referencia al estudio de Oakeshott. Como sabemos, la obra del primero se publicó en el año 1960, mientras que la del segundo investigador vio la luz un año antes. Es posible que Panofsky no pudiera llegar a consultar el manuscrito y tenerlo en cuenta a la hora de
} 
Uno de los elementos comparativos concluyentemente novedosos, pero deudores en todo caso de los avances logrados por D. Miner, reside en la importancia que el autor va a mostrar ante los resabios antiquizantes de raíz greohelenística y bizantinizante, tema que por otra parte conocía bien ${ }^{54}$. Este punto nos parece verdaderamente novedoso pues instauraba aquí una nueva vía metodológica que intentaba definir el papel que había jugado el legado antiguo romano pero tamizado por la órbita bizantina, así como su posterior recepción y reelaboración en los territorios europeos. Como es bien sabido, se trataba del inicio de una incipiente vía de análisis que sería largamente enriquecida y explotada por otros autores, en las décadas posteriores ${ }^{55}$.

En lo concerniente a las producciones plásticas del siglo XII, Oakeshott prestará una atención destacada, como referente para la escultura románica, a las piezas clásicas griegas datadas entre los siglos V al III a. de C. Aún hoy en día sorprende este método de análisis y el arcaizante corpus de obras helénicas susceptibles, según el autor, de ser comparadas con el arte románico francés. Resultan significativas, por ejemplo, las dependencias que establece entre las figuras de bronce del Hélade y la pila de SaintBarthélemy de Liege ${ }^{56}$ o la defensa de conexiones directas entre los tipos arcaicos de los denominados kouroi con respecto a ciertas esculturas presentes en las fachadas de Chartres. Sin duda, la metodología utilizada para justificar estos posibles intercambios

trazar algunas de sus teorías. En todo caso, resulta muy llamativo en este punto como los dos autores llegan a conclusiones muy semejantes.

53 Se estudian los "renacimientos" de Northumbria, la etapa carolingia y otónida y, finalmente, el sustrato antiquizante del románico europeo. En este sentido el esquema del texto de Panofsky es prácticamente idéntico.

${ }^{54}$ Otros estudios del autor profundizaron en esta asimilación de los elementos plásticos clásicos a través del tamiz bizantino y su reinterpretación durante los siglos medievales, incluso en la Península Ibérica. Cf. W. OAKESHOTT, Sigena. Romanesque Paintings in Spain. The Winchester Bible Artists, London, 1972.

${ }^{55}$ No recogemos aquí la bibliografía específica de los investigadores que se encargaron de analizar la influencia bizantina de raíz clásica en la escultura románica. Véase, por ejemplo: D. OCÓN ALONSO, "Bizantinismo y difusión de modelos en el románico periférico", VIII Congreso Español de Historia del Arte, Cáceres, 1990, pp. 307-320; ID., "Alfonso VII, la llegada de las corrientes artísticas de la corte inglesa y el bizantinismo en la escultura hispana de fines del siglo XII", Alfonso VIII y su época, Madrid, 1992, pp. 307-320; ID., "El renacimiento bizantinizante de la segunda mitad del siglo XII y la escultura monumental en España”, Viajes y Viajeros en la España Medieval, Aguilar de Campoo, 1993, pp. 267290; ID., Los modelos clásicos de la escultura monumental española: de fines del siglo XI a fines del siglo XII", Los Clasicismos del Arte Español, Madrid, 1994, pp. 67-73; ID., "La recepción de las corrientes artísticas monumentales europeas en la escultura monumental castellana en torno a 1200 ”, El arte español en épocas de transición, vol. I, León, 1994, pp. 17-26 e ID., "Castilla, León y Galicia en tiempos de Alfonso VII”, El Románico y el Mediterráneo. Cataluña, Toulouse y Pisa. 1120-1180 (M. A. Castiñeiras y J. Camps ed.), Barcelona, 2008, pp. 111-119.

${ }^{56}$ W. OAKESHOTT, Classical inspiration..., pp. 87-89. 
artísticos resultan, a los ojos del lector actual, un tanto ingenuas, si se nos permite utilizar aquí este adjetivo ${ }^{57}$.
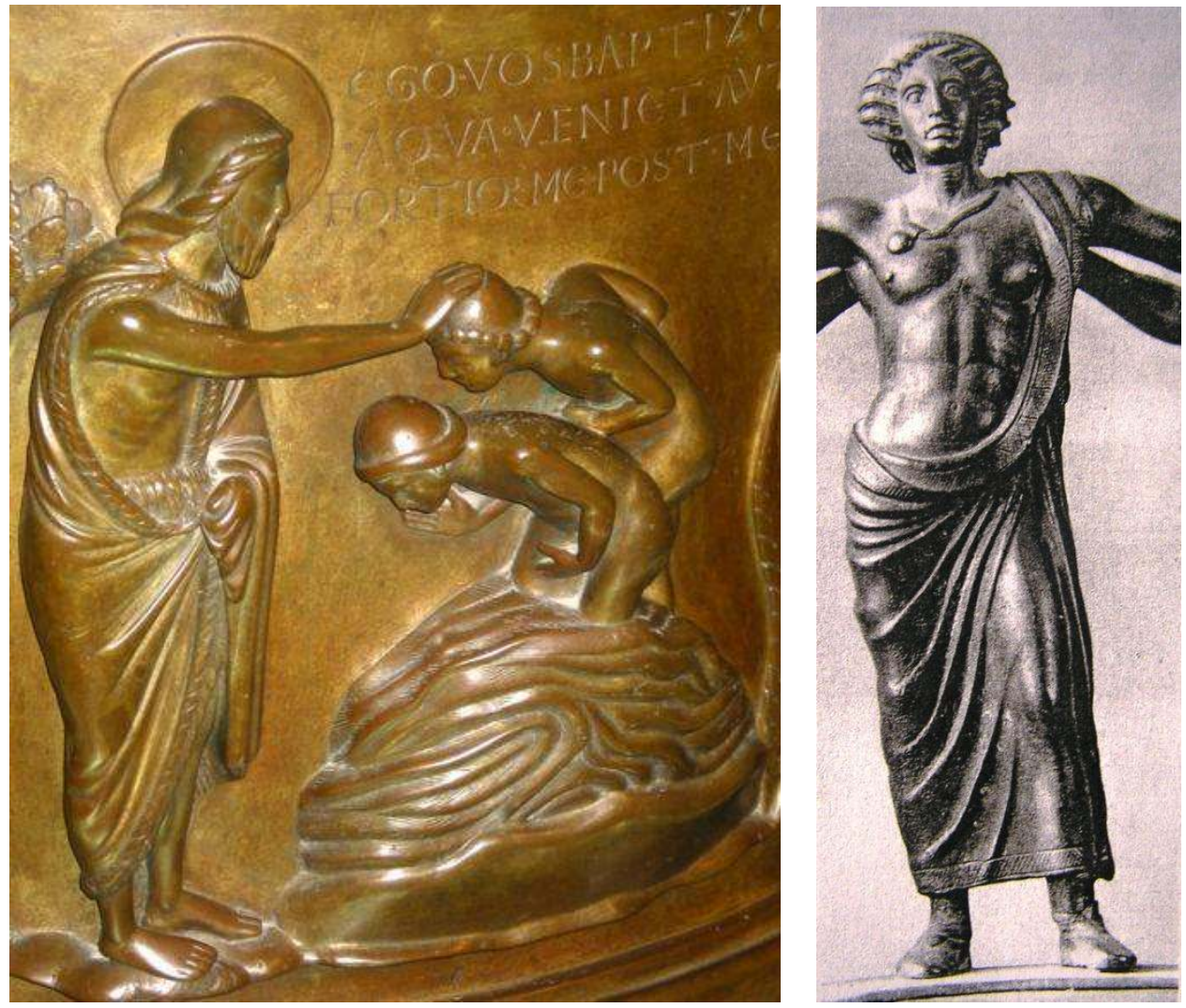

\section{Pila bautismal.}

Liège, iglesia de Saint-Barthélemy. (C) José A. Moráis Morán
Figura de bronce.

Atenas, Nuevo Museo de la Acrópolis. (Según Oakeshott).

57 Por ejemplo, compara los prototipos que llama de "sonrisa arcaica" de la catedral francesa con producciones escultóricas griegas de la isla de Chipre y datadas, aproximadamente, entre los siglos VI y V a. de. C. Cf.: Ibidem, pp. 92-93. 

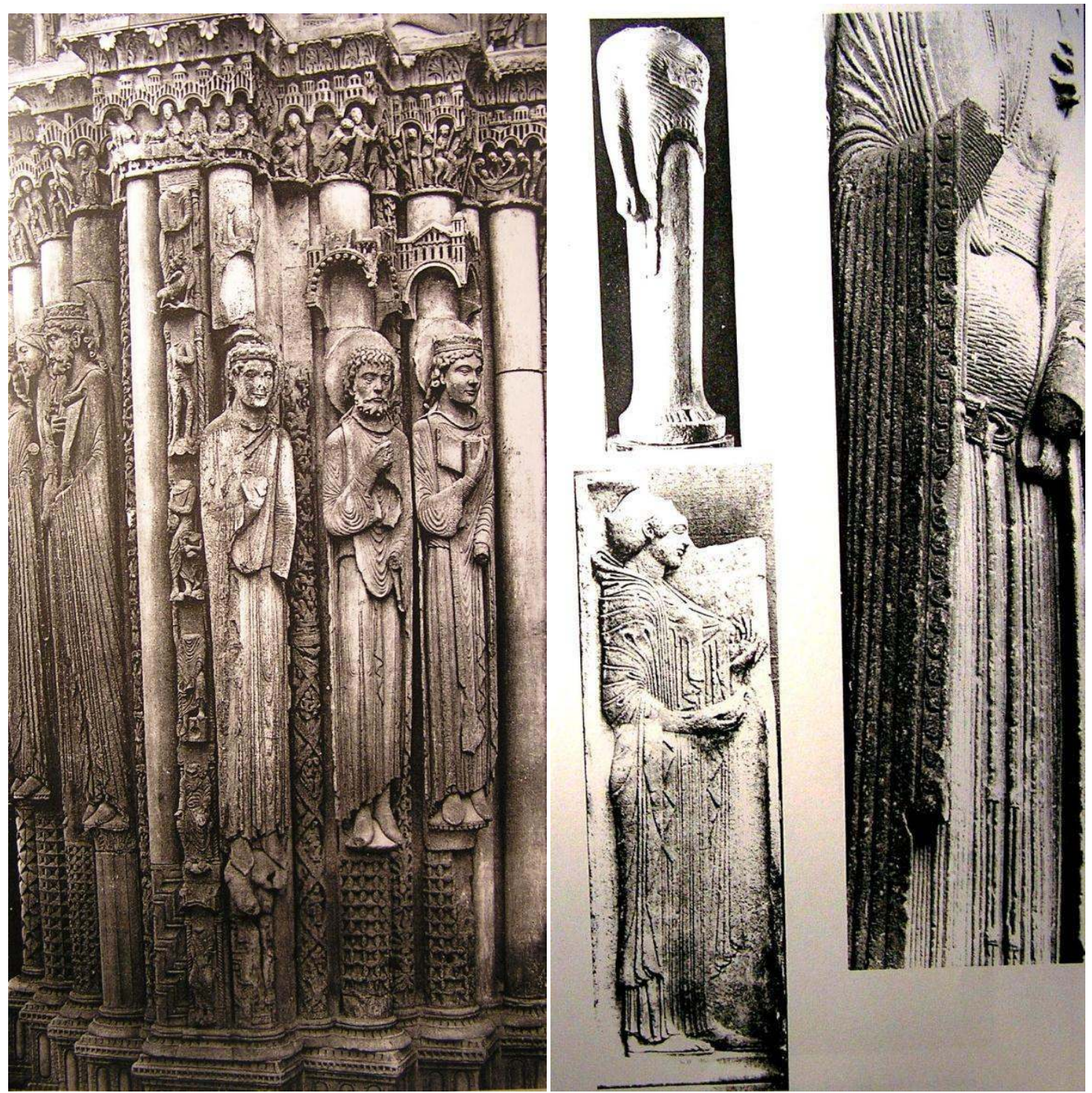

\section{Composición comparativa entre la escultura medieval y la griega.}

\section{(Según W. Oakeshott).}

A pesar del esfuerzo, un tanto formalista, realizado por Oakeshott a la hora de intentar definir el recuerdo antiguo presente en la escultura de las grandes catedrales francesas en torno al año 1150, los resultados no llegan a ser expuestos con una base fiable. La serie de composiciones fotográficas publicadas por el investigador tan sólo apuntan en una única dirección posible: defender el parentesco entre unas producciones esculpidas tan heterogéneas y alejadas en el tiempo, muy a pesar de que nunca llega a justificar tales contactos y filiaciones mediante argumentos de raigambre histórica o documental. El método acaba por delatar carencias básicas ante una necesaria demostración del 
camino seguido por este movimiento "neogriego" en su periplo mediterráneo, antes de su asimilación en la Île-de-France.

Idéntico fenómeno se aprecia en relación con otros parangones que establece en su estudio. El más llamativo deriva del análisis de los tipos faciales de los profetas de la catedral de Reims, atribuidas por Oakeshott al "Antique Master" y su confronto con respecto a una escultura de Ulises ${ }^{58}$ y al desaparecido retrato de Zeus conservado en la misma ciudad francesa hasta el año 1914. Evidentemente, ante los ojos del estudioso actual y teniendo en cuenta las bases históricas seguras que justifiquen un posible contacto entre dos momentos artísticos tan alejados, tales paralelos no deberían pasar de un mero ejercicio de analogías.

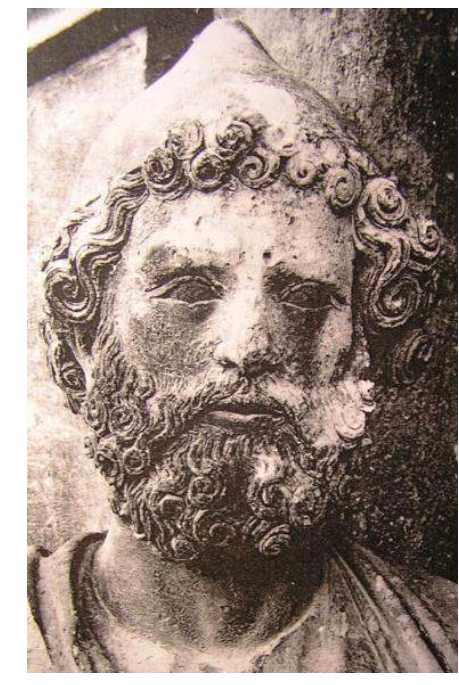

1.

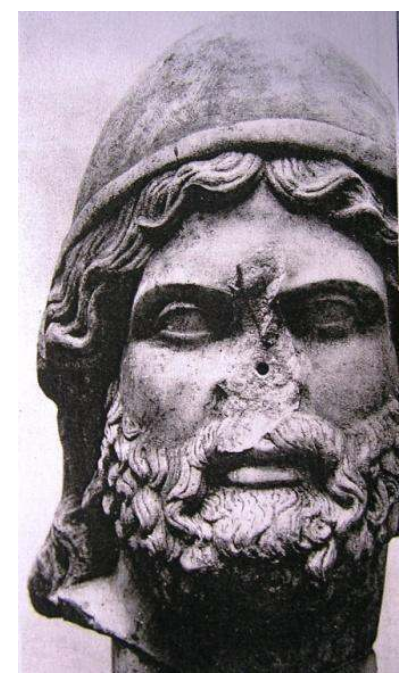

2.

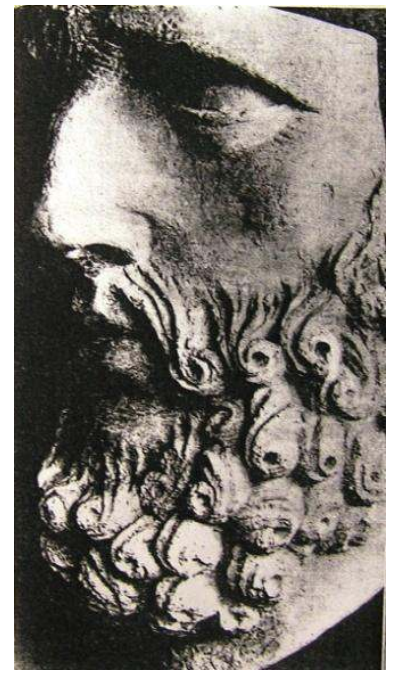

3.

Composición comparativa de W. Oakeshott.

1. San Pedro, Reims, catedral.

\section{Ulises, Roma, Museo Nazionale Romano.}

\section{Zeus, Reims, catedral (perdido en 1914).}

Las repercusiones de esta serie de comparaciones presentes en el texto de Oakeshott tendrían largo alcance. Un año después, el mismo E. Panofksy utilizará unos argumentos similares a la hora de plantear su análisis sobre el recuerdo de lo antiguo de

\footnotetext{
${ }^{58}$ Roma, Museo Nazionale Romano, datada en el siglo II a. de C.
} 
algunas de las esculturas de esa misma catedral de Reims o las que ornamentan las fachadas de la de Chartres. Así, cada una de las palabras escritas en Renacimiento y renacimientos en torno a esta cuestión acaba por transformarse en una suerte de reconstrucción verbal de la composición fotográfica que Oakeshott había utilizado como método de investigación. Y todo ello sin el menor rastro o alusión alguna a la producción científica del británico ${ }^{59}$.

Coincidiendo con W. Oakeshott, Panofsky considera la escultura de Reims como representante de un "clasicismo intrínseco", visible, según señala, al comparar la magnífica figura de San Pedro de Reims con respecto al retrato de Antonino Pío del Museo Nazionale de Roma ${ }^{60}$. Tampoco olvida el alemán incluir aquí la mención a la desaparecida cabeza marmórea de Ulises que, como hemos visto, no pasó desapercibida para Oakeshott ${ }^{61}$.
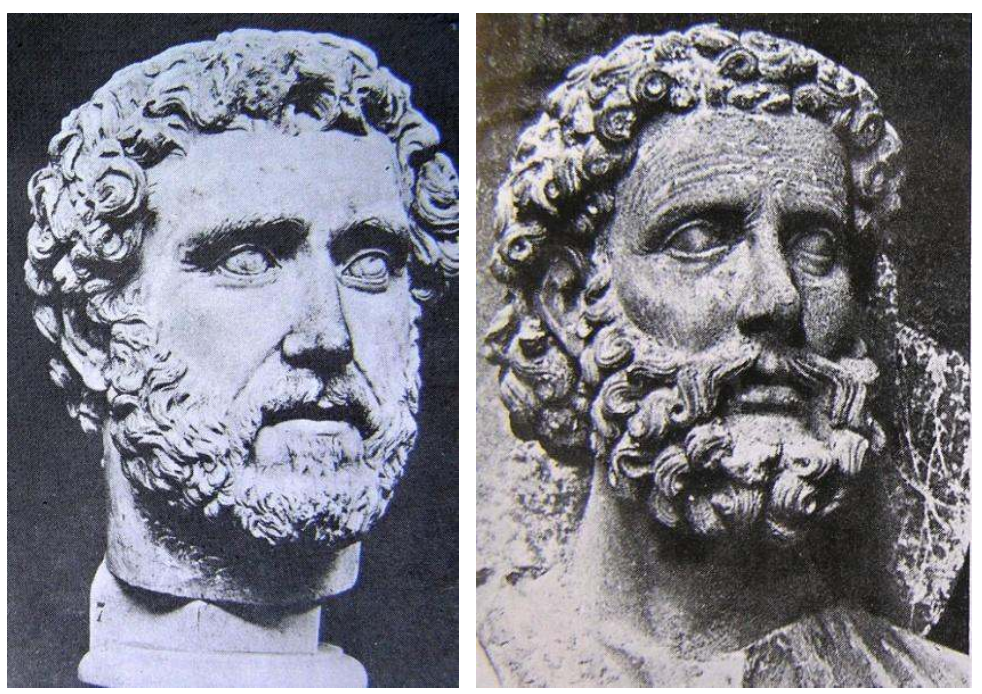

1.

2.

\section{Antonino Pio, Roma, Museo Nazionale Romano.}

\section{San Pedro, Reims, catedral.}

\footnotetext{
${ }^{59}$ Como hemos expuesto, ni en el texto original ni en la compilación bibliográfica final del libro de Panofsky aparece mención ninguna a la investigación de Oakeshott.

${ }^{60}$ E. PANOFSKY, Renacimiento y renacimientos..., p. 109.

${ }^{61}$ Ibidem, pp. 109-110.
} 
En el corto espacio de un año y con la aparición de dos obras científicas de gran relevancia, el análisis del legado antiguo sobre la escultura medieval europea asentaba así una de sus principales vías de estudio para el futuro. La llegada de esta serie de “oleadas bizantinizantes (...) barrió toda Europa", especialmente "en lo que había sido el corazón mismo del imperio carolingio y había de serlo igualmente del estilo altogótico: la Lorena, la Île-de-France y la Champagne, donde los artistas supieron aislar lo que aún había de helénico en el estilo bizantino ${ }^{62}$.

La Historia del Arte y una historia del arte de las influencias antiguas sobre la escultura románica quedaba ya codificada para el futuro a través de esta visión "bipolarizada" del fenómeno. En lo sucesivo los análisis se centrarían en intentar separar y disgregar de la obra románica los ecos de una tradición propiamente romana clásica occidental o, por el contrario, sopesar la metamorfosis que ese sustrato romano había sufrido bajo la fuerza demoledora de la estética bizantina, en su viaje desde las áreas orientales del orbe.

La definición o, al menos, la consciencia de poder llegar a vislumbrar dos formas tan diferentes de entender la influencia del arte antiguo sobre la escultura medieval se nos presentaba, ya durante la década de los años sesenta del siglo pasado, como una de las mayores novedades científicas en estas materias. Tal grado de renovación y contemporaneidad que impregnaba estas teorías acabó, paradójicamente, evocando en la memoria de la colectividad científica, aunque con ciertos tintes metafóricos o poéticos, las hoy lejanas palabras eruditas de viajeros y estudiosos de los siglos XVIII y XIX. Siglos en los que, confirmando el bucle metodológico en el que parece que hoy está inmersa nuestra disciplina; la escultura que definimos como románica gozó durante lustros del quimérico calificativo de "bizantina". Parece claro entonces que, como en la etapa decimonónica, hemos llegado a comprender que para afrontar la comprensión de la escultura románica resulta necesario encuadrar tales obras artísticas en el extenso panorama de la plástica de la Antigüedad. Allí donde se encuentran las bases más profundas del arte de los siglos XI y XII.

\footnotetext{
${ }^{62}$ Ibidem, p. 109.
} 


\section{BIBLIOGRAFÍA}

ADHÉMAR, Jean, Influences antiques dans l'art du Moyen-âge français : recherches sur les sources et les thèmes d'inspiration, London: The Warburg Institute, 1937, 319 p. BALTRUŠAITIS, Jurgis, Le Moyen Âge fantastique. Antiquités et exotismes dans l'art gothique, Paris: A. Colin, 1955, 299 p.

BANGO TORVISO, Isidro Gonzalo, "Crisis de una historia del arte medieval a partir de la teoría de los estilos. La problemática de la Alta Edad Media”, in: Revisión del arte medieval en Heuskal Herria, 15 (1995), pp. 15-28. ISBN: 84-89516-06-5.

ID., “Un gravísimo error en la historiografía española, el empleo equivocado del término mozárabe", in: El legado de Al-Andalus. El arte andalusí en los reinos de León y Castilla durante la Edad Media (M. Valdés Fernández coord.), León: Fundación del Patrimonio de Castilla y León, 2007, pp. 73-88. ISBN: 978-84-933024-9-8. 424 p.

BARASCH, Moshe, Teorías del arte. De Platón a Winckelmann, Madrid: Alianza Editorial, 1999. ISBN84-206-7940-2. 311 p.

BARRAL I ALTET, Xavier, Contre l'art roman ? essai sur un passé réinventé, Paris : Librairie Arthème Fayard, 2006, ISBN 978-2-213-60887-7. 415 p.

BERTAUX, Émile, "La Sculpture chrétienne en Espagne des origines au XIVe siècle", in: Histoire de l'art, depuis les premiers temps chrétiens jusqu'à nos jours (M. André dir.), 18 vols., Paris, 1906, vol. II, pp. 214-295.

BOSARTE, Isidro, Viaje artístico a varios pueblos de España con el juicio de las obras de las tres nobles artes que ellos existen y épocas a que pertenecen, Madrid, 1804.

BURCKHARDT, Jacob, Die Kultur der Renaissance in Italien, Basilea, 1860.

BURKE, Peter, El Renacimiento, Barcelona: Crítica Barcelona, 1999, ISBN 84-7423982-6. $121 \mathrm{p}$.

CAMPOS SÁNCHEZ-BORDONA, María Dolores, El arte del Renacimiento en León: las vías de difusión, León: Servicio de Publicaciones de la Universidad de León, 1992, ISBN 84-7719-255-3, 129 p. 
CASTIÑEIRAS GONZÁLEZ, Manuel Antonio, "Capitel románico inspirado na Orestíada do sarcófago de Husillos", in: Luces de Peregrinación, Santiago de Compostela: Xunta de Galicia, 2004, pp. 252- 254. ISBN 8445337009. 460 p.

ID., "Verso Santiago? La sculptura romanica de Jaca a Compostella", in: Medioevo: l'Europa delle cattedrali, Milano: Jaca Books, 2007, pp. 387-396. ISBN 978-88-1640778-7. $352 \mathrm{p}$.

CAUMONT, Arccise de, Essai sur l'architecture du moyen âge, particulièrement en Normandie, Paris: Derach, 1824. 438 p.

ID., Abécédaire ou rudiment d'archéologie, Paris: E. Derache, 1858. 498 p.

COURCELLE, Pierre, "La tradition antique dans les miniatures inédites du Virgile de Naples”, in: Mélanges d'archéologie et d'histoire, 56 (1939), pp. 249-279.

CROZET, René, 'De l'art romain à l'art roman. Recherches sur quelques ordonnances architecturales", in: XVII Congrès international d'histoire de l'art, Amsterdam: Éditions Amsterdam, 1952, 559 p.

DURAND LEFEBVRE, Marie, Art gallo-romain et sculpture romane. Recherches sur les formes, Paris: Durassié, 1937. 384 p.

DURLIAT, Marcel, La sculpture romane de la route de Saint- Jacques. De Conques à Compostelle, Mont-de-Marsan: Comité d'études sur l'histoire et l'art de la Gascogne, 1990, ISBN 2-9501584-1-2. 508 p.

FONT-REAULX, Dominique de, "Les audaces d'une position française", in: Études photographiques, 25 mai 2010, pp. 70-105.

en http://etudesphotographiques.revues.org/index3059.html, consultado el 29 de septiembre de 2010.

GERVILLE, Charles de y GUIBERT, Michel, Voyage archéologique dans la Manche (1818-1820), (reed. 5 vols, 1999-2002), vol. I, Paris: Société d'Archéologie et d'Histoire de la Manche, 1999, ISBN 2914329075. 477 p.

GOLDSCHMIDT, Adolph, "Das Nachleben der antiken Formen im Mittelalter", in: Vorträge der Bibliothek Warburg, I, (1921-1922), pp. 40-50. 
GOMBRICH, Ernst H. J., La Historia del Arte, Madrid: Alianza Editorial, 2008, ISBN $9780714898704.688 \mathrm{p}$.

ID., The Story of Art, London: Phaidon, 1950. ISBN 9780714839813. 688 p.

GRAF, Arturo., Roma nella memoria e nelle immaginazioni del Medio Evo, Torino: Loescher, 1882.

GRODECKI, Louis, The Year 1200. A Symposium, New York: Metropolitan Museum of Art, 1975.

ID., The Year 1200. A Background Survey, New York: Metropolitan Museum of Art, 1970. $354 \mathrm{p}$.

ID., "Le Style 1200”, Encyclopedia Universalis, Supplément II, Paris: Encyclopaedia Universalis, 1980, pp. 1337-1340. ISBN 2-85229-281-5.

HARMANN, Richard, Deutsche und französische Kunst im Mittelalter. I. Südfranzösische Protorenaissance und ihre Ausbreitung in Deutschland auf dem Wege durch Italien und sie Schweiz, Marburg: Kunstgeschichtliches Seminar, 1922. 139 p.

HASKINS, Charles H., The Renaissance of the Twelfth Century, Cambridge: Harvard University Press, 1927, ISBN 0-674-76075-1, 437 p.

HUBERT, Jean, “Archéologie médiévale”, in: L'Histoire et ses méthodes (Ch. Samarán ed.), Paris: Encyclopédie de la Pléiade, 1961, pp. 275-328. 1171 p.

JULLIAN, René, "L'art de la draperie dans la sculpture romane de Provence", in: Gazette des Beaux-Arts, II (1928), pp. 241-258.

ID., "Les survivances antiques dans la sculpture lombarde", in: Études italiennes, I, (1931), pp. 131-140.

LACHENAL, Lucilla de, Spolia. Uso e reimpiego dell'antico. Dal III al XIV secolo, Milano: Longanesi, 1995, ISBN 88-304-1313-5, 442 p.

LANDER, G. B., "Some recent publications on the classical tradition in the Middle Ages and the Renaissance and on Byzantium”, in: Traditio, 10 (1954), pp. 578-594.

MINER, Dorothy, The survival of Antiquity in the Middle Ages. The Greek tradition, Baltimore, 1939. 
MOE, Émile-A. van, “Jean Adhémar. Influences antiques dans l'art du Moyen-âge français : recherches sur les sources et les thèmes d'inspiration, Londres, the Warburg Institute, 1937, In-8 ${ }^{\circ}$ XVII-319 p. et XL planches et phototypie”, in Bibliothèque de l'école des chartes, vol. 99, 1, (1938), pp. 380-382.

MORALEJO ÁLVAREZ, Serafín, "Sobre la formación del estilo escultórico de Frómista y Jaca”, in: Actas del XXIII Congreso Internacional de Historia del Arte, vol. I, Granada, 1973, pp. 427-434, consultado en Patrimonio artístico de Galicia y otros estudios: homenaje al Prof. Dr. Serafín Moralejo Álvarez (A. Franco Mata coord.), 3 vols., Santiago de Compostela: Xunta de Galicia, 2004, ISBN 84-453-3587-1, vol. I, pp. 65-70. 327 p.

ID., "San Martín de Frómista en los orígenes de la escultura románica europea", in: Jornadas sobre el Románico en la Provincia de Palencia, Palencia, 1985, pp. 28-37, consultado en Patrimonio artístico de Galicia y otros estudios: homenaje al Prof. Dr. Serafín Moralejo Álvarez (A. Franco Mata coord.), 3 vols., Santiago de Compostela: Xunta de Galicia, 2004, ISBN 84-453-3588-X, vol. II, pp. 61- 64. 320 p.

MOREY, Charles Rufus, “The sources of mediaeval style”, Art Bulletin, 7 (1924), pp. $35-50$.

MÜNTZ, Eugène, "La tradition antique chez les artistes du Moyen Âge", Journal des savants (1887), pp. 629-642.

MURATORI, Ludovico Antonio, Antiquitates italicae medii aevi, Milano, 1739, vol. II, cols. 349-296.

OAKESHOTT, Walter F., Classical Inspiration in Medieval Art, London: Champan \& Hall, 1959, 145 p.

ID., Sigena. Romanesque Paintings in Spain. The Winchester Bible Artists, London: Harvey Millar \& Medcalf, 1972. ISBN. 85602007 9. 144 p.

ORTUETA HILBERATH, Elena de, "La visión de la construcción medieval desde la óptica de la era industrial", in: Libros con Arte. Arte con libros, Cáceres: Junta de Extremadura, Consejería de Cultura y Turismo: Universidad de Extremadura, 2007, ISBN. 978-84-9852-026-2, pp. 565-581. 257 p. 
PANADERO PEROPADRE, Nieves, "La definición del estilo románico en la historiografía española del romanticismo", in: Anales de historia del arte, 7, (1997), ISSN 0214-6452, pp. 245-256.

PANOFSKY, Erwin, Renaissance and Renascences in Western Art, Copenhagen: Russak, 1960. ISBN. 0-203-34487-1. 157 p.

PANOFSKY, Erwin y SAXL, Fritz, "Classical Mythology in Medieval Art”, in: Metropolitan Museum Studies, 4 (1932-1933), pp. 228-280.

PAPA MALATESTA, Vittoria, "Émile Bertaux", in: Dictionnaire critique des historiens de l'art actifs en France de la Révolution à la Première Guerre mondiale (Ph. Sénéchal y C. Barbillon dir.), Paris: Edition du INHA (2009), consultado el 9 de junio de 2010: http://www.inha.fr/spip.php?article2196.

PLAZAOLA, Juan, Modelos y teorías de la Historia del Arte, San Sebastián: Universidad de Deusto, 1987. ISBN: 978-84-9830-100-7. 120 p.

PRADO-VILAR, Francisco, "Del maestro de Orestes-Caín al maestro del sátiro: una conferencia sobre la belleza de la tragedia y la memoria del futuro", in: Maestros del románico en el Camino de Santiago, Aguilar de Campoo: Fundación Santa María la Real, 2010. ISBN 978-84-89483-71-2, pp. 11-46. 240 p.

ID., "Saevum facinus: Estilo, genealogía y sacrificio en el arte románico español”, in: Goya, 324 (2008), ISSN 0017-2715, pp. 173-199.

ID., "Lacrimae rerum: San Isidoro de León y la memoria del padre", in: Goya, 328, (2009), ISSN 0017-2715, pp. 195-221.

PRESSOYRE, Léon, "Préface", Influences antiques dans l'art du Moyen Âge français, Paris: Éd. du CTHS, 1996, ISBN, 2-7355-0332-1, 463 p.

REY, Raymond, "Quelques survivances antiques dans la sculpture romane du Midi de la France", Gazette des Beaux- Arts, II (1928), pp. 173-191.

SAXL, Fritz, "Rinascimento dell'antichitá. Studien zu den Arbeiten A. Warburgs”, in: Repertorium für Kunstwissenschaft, 43 (1922), pp. 220-272.

SENRA GABRIEL Y GALÁN, José Luís, "Architecture et décor dans le contexte de la colonisation clunisienne des royaumes septentrionaux de la péninsule ibérique", in: Hauts Linux romans dans le sud de l'Europe (XI-XII siècles). Moissac, Saint-Jacques 
de Compostelle, Modène, Bari..., Cahors: La Louve éditions Centre Marcel Durliat, 2008. 286 p, ISBN 978-2-916488-10-3, pp. 11-70.

SESTAN, Enrico. "Tardo antico e alto Medievale: Difficoltà di una periodizzazione”, in Atti delle IX Settimane di Studio del Centro Italiano di studi sull'Alto Medioevo. Il passaggio dall'Antichità al Medieoevo in Occidente, IX, Spoleto: Sede del Centro, 1962, pp. 15-37. 678 p.

SETTIS, Salvatore, "Continuitá, distanza, conoscenza. Tre usi dell'antico”, Memoria dell’antico nell’arte italiana, Dalla tradizione all’archeología (a cura di S. Settis), 3 vols, Torino: G. Einaudi, 1986, ISBN 88-06-57869-3, vol. III, pp. 372-486. 539 p.

SEZNEC, Jean, La survivance des dieux antiques: essai sur le rôle de la tradition mythologique dans l'humanisme et dans l'art de la Renaissance, London: Studies of the Warburg Institute, 1940. 372 p.

SOUCHAL, François, “Chronique. Nécrologie. Jean Adhémar”, in: Bibliothèque de l'école des chartes, 146-2 (1988), pp. 457-458.

VALLERY-RADOT, Jean, “Georges Gaillard. Premiers essais de sculpture monumentale en Catalogne aux Xe et XIe siècles, Paris-Paul Hartmann, 1938. In-4º de 112 pages, 16 planches hors texte. Les débuts de la sculpture romane espagnole: León, Jaca, Compostelle, Paris-Paul Hartmann, 1938. In-4º de XXXV- 270 pages, 218 planches hors texte”, in: Revue d'histoire de l'Église de France, 107, vol. 25 (1939), pp. 214-219.

WILLIAMS, John, "El románico en España: diversas perspectivas”, Alfonso VIII y su época, Aguilar de Campoo: Centro de Estudios del Románico, 1992, ISBN 84-6008212-1, pp. 9-20. 396 p.

YVARS, J. F., "Erwin Panofsky", in: Historia de las ideas estéticas y de las teorías artísticas contemporáneas (Valeriano Bozal Fernández coord.), Madrid: Visor, 1996, ISBN 84-7774-581-1, vol. 2, pp. 248-251. 


\section{COMO CITAR ESTE ARTIGO}

\section{Referência electrónica:}

MORÁIS MORÁN, José Alberto - "Un largo proceso en la definición historiográfica de las fuentes del arte medieval: el arte antiguo como referente para la escultura románica”. Medievalista [Em linha]. №9, (Dezembro de 2010). [Consultado dd.mm.aaaa]. Disponível em http://www2.fcsh.unl.pt/iem/medievalista/MEDIEVALISTA9lmoran9006.html. ISSN 1646-740X.

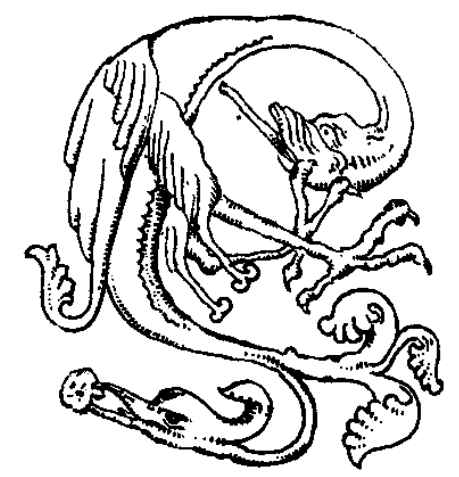

